\title{
$\begin{array}{lllllllllllllllll}\mathbf{R} & \mathbf{O} & \mathrm{Z} & \mathbf{P} & \mathbf{R} & \mathbf{A} & \mathbf{W} & \mathbf{Y} & \text { I } & \text { A } & \mathbf{R} & \mathbf{T} & \mathbf{Y} & \mathrm{K} & \mathbf{U} & \mathbf{L} & \mathbf{Y}\end{array}$
}

ks. Ginter Dzierżon

Ius Matrimoniale

28 (2017) $\mathrm{nr} 4$

DOI:10.21697/im.2017.28.4.01

Wydział Prawa Kanonicznego UKSW

\section{Walor prawny małżeństw tajnych w epoce kanonistyki klasycznej}

\section{Wstęp}

W obecnie obowiązującej kodyfikacji specyficzną formę zawierania małżeństwa stanowi zawieranie małżeństw tajnych (kan. 1130-1133 KPK). Na przestrzeni dziejów instytucja ta, obecnie w praktyce śladowa, przeszła długą ewolucję. W opracowaniu tym przedmiotem uwagi stanie się tematyka sporadycznie podejmowana w kanonistyce, jaką jest problem waloru prawnego małżeństw tajnych zawieranych w epoce kanonistyki klasycznej. Tak określony cel badawczy ukształtował strukturyzację tego artykułu. W pierwszej kolejności uwaga zostanie skupiona na kwestii zasad funkcjonowania małżeństw tajnych. Podjęcie tego wątku byłoby jednak niezrozumiałe bez odniesienia do średniowiecznego kontekstu doktrynalnego dotyczącego natury małżeństwa. Dlatego też w dalszej kolejności zostanie przedstawione to zagadnienie. Analizy te zwieńczy tematyka kluczowa tego opracowania, jaką jest problem waloru prawnego formalności prawnych w ówczesnej strukturze prawnej małżeństwa. Znaczenie prawne bowiem wymogów formalnych w głównej mierze rzutowało na walor małżeństw tajnych zawieranych w średniowieczu. 


\section{Funkcjonowanie małżeństw tajnych}

Poważnym problemem zarówno egzystencjalnym, jak i prawnym w średniowiecznej rzeczywistości stanowiły małżeństwa tajne. We współczesnej doktrynie spotykamy się z różnymi definicjami tego typu związków. Zdaniem Jean’a Gaudemet, tajność małżeństw, o których mowa, wiązała się z odrzuceniem publiczności ${ }^{1}$. Według Piero Rasi przez małżeństwa tajne rozumiano związki celebrowane bez przyzwolenia ojca, bądź też nieposiadające charakteru publicznego ${ }^{2}$. Odzwierciedlenie tych zasad znajdujemy w poglądach dekretystów i dekretalistów. Bernard z Pawii utrzymywał, iż szło o małżeństwa zawierane z pominięciem formalności prawnych ${ }^{3}$. Bardziej rozbudowaną definicję małżeństw tajnych przytoczyli Rufinus i Goffredus de Trano. Rufinus w „Summa decretorum” mówiąc o takich związkach miał na myśli małżeństwa zawierane bez obecności świadków, z pominięciem formalności prawnych oraz błogosławieństwa ${ }^{4}$. Goffredus de Trano z kolei w „Summa super titulis Decretalium” pisał o dwóch formach małżeństw tajnych, jakimi były związki zawierane bez obecności świadków, a także związki zawierane z pominięciem formalności prawnych ${ }^{5}$.

Jak zauważył Gaudemet, zawierania takich małżeństw nie należało błędnie rozumieć $w$ tym sensie, iż w tym wypadku pomijano jakikolwiek ryt religijny. Opisując zawieranie małżeństw tajnych pisał on, iż wszystko dokonywało się dyskretnie nie w kościele, czy też w kaplicy

1 Por. J. Gaudemet, Il matrimonio in occidente, tłum. B. Pistocchi, Torino 1996, s. 173: „La clandestinità può essere semplicemente il rifiuto di qulasiasi pubblicità, senza per questo il matrimnio sia segreto".

2 Por. P. RAsi, La conclusione del matrimonio nella dottrina prima del Concilio di Trento, Napoli 1958, s. 159.

3 Por. Bernardi Papiensis, Summa decretalium, Ed. T. Laspeyeres, Graz 1860, s. 141.

4 Por. Rufinus, Summa decretorum, Ed. H. Singer, Paderborn 1963, s. 468: „Est autem coniugum clandestinum quo occulte sine presentia testium, sine sollemnitate traductionis, benedictionis et velaminis contrahitur".

5 Por. Goffredus de Trano, Summa super titulis Decretalium, Aalen 1968, s. 175. 
książęcej, ale w miejscu odosobnionym jakim mogła być na przykład kaplica zakonna, czy też kaplica opactwa cieszącego się egzempcją. Prawnie takie związki były ważne. Nie można było bowiem wnieść skargi przeciw jurysdykcji władzy miejsca wyjętego; natomiast na osobę, która nie zawarła małżeństwa we własnej parafii porzucając ją można było jedynie nałożyć karę pieniężną ${ }^{6}$. W literaturze przedmiotu wskazuje się, iż jednym z głównych powodów zawierania małżeństw tajnych było pokonanie oporu rodziców ${ }^{7}$. Dlatego też miały one charakter niepubliczny ${ }^{8}$.

\section{Tło historyczne}

W XII w. pozycja Kościoła w ówczesnym świecie pozwoliła mu na stworzenie własnego systemu prawnego ${ }^{9}$. W średniowiecznej rzeczywistości posiadał on jurysdykcję nad małżeństwem ${ }^{10}$. Ten szczególny status wyrażał się m. in. w tym, że wyłącznie Kościół dysponował władzą ustawodawczą w odniesieniu do małżeństwa ${ }^{11}$. Jak pisał Luigi Nuzzo, rewolucyjne jak na owe czasy dokonania Kościoła wyrażały się nie tylko w ujęciu małżeństwa w kategorii sakramentu wynikającego z natury małżeństwa ${ }^{12}$, ale także w zdefiniowaniu go jako kontraktu

\footnotetext{
6 Por. J. Gaudemet, Il matrimonio..., dz. cyt., s. 173-174: „Un’unione sifatta non rifiuta i riti religiosi (benedizione di un sacerdote, messa di matrimonio). Ma tutto viene fatto segretamente. Non nella chiesa del villaggio o del quartiere, e nemmeno in qualche cappella signorile, ma in un luogo discreto, in una cappella del convento, talvolta in una abbazia che gode dell'essenzione". [...] L'unione era perfettamente valida. Nessuna azione può essere intentata contra autorità del luogo essente. Può essere comminata solo una ammenda per abbandono della propria parocchia”.

7 TAMżE, s. 174.

8 Por. P. Rasi, La conclusione del matrimonio..., dz. cyt., s. 159.

9 Por. L. Nuzzo, Il matrimonio clandestino nella dottrina canonistica del basso medioevo, w: Studia et documenta historiae et iuris, red. F. Amarelli, Roma 1998, s. 351.

10 TAMżE, s. 352.

11 Por. J. Gaudemet, Il matrimonio..., dz. cyt., s. 105-106.

12 Por. Cz. RYснцiскі, Sakramentalny charakter przymierza małżńskiego, Płock 1997, s. 260-261.
} 
konsensualnego, którego istota polegała na wyrażeniu zgody małżeńskiej przez nupturientów ${ }^{13}$. Należy też dodać, iż w badanym okresie wprowadzono szereg wymogów dodatkowych do zawarcia małżeństwa, zwanych formalnościami prawnymi (sollemnia). W literaturze przedmiotu wskazuje się na: udział urzędnika publicznego, obecność notariusza, badanie wstępne (interrogationes), wyrażenie zgody odpowiednimi słowami, roczną płatność (datio annuali), błogosławieństwo małżeńskie, obecność świadków, a także zaprowadzenie kobiety do domu męża (traductio mulieris in domum mariti) ${ }^{14}$.

Rozważając ten problem nie można też abstrahować od faktu, iż w XII w. pojawiła się doktrynalna polemika w kwestii, czy samo wyrażenie konsensu przez strony kontraktu wystarczy do ważnego zawarcia związku małżeńskiego? ${ }^{15}$. W komentarzu do C. 30, q. 5 takie autorytety ${ }^{16}$, jak: Rolandus Bandinelli ${ }^{17}$, Rufinus ${ }^{18}$, czy też Bernard z Pawii mówili o zakazie zawierania małżeństw tajnych ${ }^{19}$. Wobec takiego stanu prawnego średniowieczni uczeni stali przed zasadniczym pytaniem: jaki był walor tych wymogów prawnych? Ich wątpliwości sprowadzaly się do pytania: czy formalności prawne były wymogami wymaganymi do ważności małżeństwa, czy też nie miały takiego charakteru?

13 Por. L. Nuzzo, Il matrimonio clandestino..., dz. cyt., s. 351. Szerzej w kwestii dyskusji prowadzonej na ten temat pomiędzy szkołą bolońską i paryską zob. I. FAHNER, Geschichte der Ehescheidung in kanonischen Recht, Freiburg im Breisgau 1903, s. 123-145; G. Marchetto, Il divorzio imperfetto. I giuristi medievali e la separazione dei coniugi, Bologna 2008, s. 43-106; W. Plöchl, Geschichte des Kirchenrechts, t. 2, München 1953, s. 305-306.

14 Por. P. Rasi, La conclusione del matrimonio..., dz. cyt., s. 150-208.

15 Por. K. E. Moy, Das Eherecht der Christen in der morgenländischen abendlendischen Kirche bis zur Zeit Karls des Grossen, Regensburg 1833, s. 366.

16 Szerzej na temat roli dekretystów w ówczesnej kanonistyce zob. E. CorTese, Il diritto nella storia medievale, Roma 1995, s. 221-223.

17 Por. Summa Magistri Rolandi, Ed. F. Thaner, Innsbruck 1874, s. 153.

18 Por. Rufinus, Summa decretorum, dz. cyt., s. 468.

19 Por. Bernardi Papiensis, Summa..., dz. cyt., s. 141. 


\section{Walor formalności prawnych}

Jedynie nieliczni badacze, tacy jak Brandilone i Bizzari na podstawie badań nad włoskimi archiwami notarialnymi utrzymywali, iż wypełnienie „sollemnitates” było wymagane do ważności małżeństwa. Twierdzili oni, iż związki małżeńskie w owym czasie były zawierane w obecności notariusza ${ }^{20}$. Tezę tą podważył Rasi wskazując, iż takie rozwiązania dotyczyły jedynie małej grupki małżeństw ${ }^{21}$. Popierając swe twierdzenie włoski uczony zwrócił uwagę, iż Brandilone i Bizzari poddali analizie wyłącznie jedną kategorię źródeł; nie przebadali natomiast innej bazy źródłowej związanej z procesami ustnymi o stwierdzenie nieważności małżeństwa, a także abstrahowali od ówczesnej doktryny kanonistycznej w tej materii ${ }^{22}$. Poza tym Rasi pisze, iż w dostępnych źródłach cywilistycznych nie zajęto stanowiska w tej kwestii ${ }^{23}$; takie stanowisko natomiast zajęli kanoniści twierdząc, iż formalności prawne nie były wymagane do substancji celebracji związku małżeńskiego. W myśl bowiem ówczesnej doktryny, tak ważki komponent jakim jest sakramentalność małżeństwa urzeczywistniał się poprzez wzajemne wyrażenie małżeńskiego konsensu przez nupturientów ${ }^{24}$.

Prezentując kwestię waloru prawnego wymogów formalnych trzeba również prześledzić poglądy średniowiecznych kanonistów w tej kwestii. I tak Mistrz Gracjan twierdził, iż małżeństwa tajne nie powinny być zawierane ${ }^{25}$. W przekonaniu tego wybitnego przedstawiciela szkoły bolońskiej, nie wypełnienie formalności prawnych decydowało o ważności związku, ale współżycie stron ${ }^{26}$. Gracjan

\footnotetext{
20 Por. P. Rasi, La conclusione del matrimonio..., dz. cyt., s. 153.

21 TAMŻE.

22 TAMŻE, s. 154.

23 TAMŻE, s. 155.

24 TAMŻE, s. 156.

25 Por. C. 30, q. 5, c. 1-3.

26 Por. C. 30, q. 5, c. 17; C. 27, q. 2, c. 34; C. 28, q. 1, c. 17; J. Freisen, Geschichte des kanonischen Ehrerecht bis zum Verfall der Glossenliteratur, Reprint, Aalen 1963, s. 172 .
} 
i szkoła bolońska stała na stanowisku, iż małżeństwo nieskonsumowane było tylko „matrimonium initiatum”27. Według Josepha Freisena, stanowisko Mistrza Gracjana korespondowało z rozwiązaniem przyjętym w prawie żydowskim ${ }^{28}$. Gracjanowe ujęcie organicznie wpisuje się również w nurt reprezentowany przez Hinkmara $\mathrm{z}$ Reims i szkołę z Laon w której utrzymywano, iż konsumacja jest elementem istotnym małżeństwa-sakramentu ${ }^{29}$. Podstawą doktrynalną takiego ujęcia była przesłanka teologiczna, iż obrazem takiego związku był mistyczny związek Chrystusa ze swoim Kościołem ${ }^{30}$.

O zakazach zawierania tego typu związków pisali także dekretyści w komentarzach do C. 30, q. 5. Rolandus Bandinelli w „Summa” podkreślał, iż pominięcie „sollemnitates” nie skutkowało nieważnością małżeństwa ${ }^{31}$. Rufinus z kolei w „Summa decretorum” wyraził pogląd zgodnie z którym, zawieranie małżeństw tajnych było zabronione „propter cautelam”32. Wreszcie Bernard z Pawii wskazywał, iż formalności prawne są wymagane do godziwości, nie zaś do ważności zawieranego związku³

27 Por. A. Bucci, Dispensa super rato e non consumato. Evoluzione storica e problematica giuridica, Napoli 2011, s. 17.

28 Por. J. Freisen, Geschichte..., dz. cyt., s. 173.

29 Por. F. Schulte, Handbuch des katholischen Eherecht nach dem gemeinem katholischen Kirchenrecht und dem österreichischen, preussischen, französischen: Partikularrechte mit Rücksichtname und noch andere Civilgesetzgebungen, Gießen 1855, s. 87. W przypisie 13 będącym komentarzem do C. 27, q. 2, c. 29 znalazły się takie słowa: „Ecce impossibilitas coeundi, si post carnalem copulam inventa fuerit in aliquo solvit conjugum"; G. MAвснетто, Il divorzio imperfetto..., dz. cyt., s. 47-48. 30 Por. A. Bucci, Dispensa..., dz. cyt., s. 13.

31 Por. Summa Magistri Rolandis. 153: „In hoc capitulo demonstartur, quae sint observanda in matrimonio contrahendo, quae licet omnia non interveniat, non minus tamen inter eos erit matrimonium".

32 Por. Rufinus, Summa decretorum, s. 468: „Coniugia itaque clandestina prohibita sunt, non quin sint coniugia occulte contracta-cum solus consensus faciat matrimonium, ut supra dictum est, sed propter cautelam. [...] Clandestina ergo coniugia contrahi non debent; si vero contra facta fuerint, non separabuntur".

33 Por. Bernardi Papiensis Summa decretalium, dz. cyt., s. 141: „[...] clandestina, quae sollemnitatibus caret, quod ille sollemnitates de honestate sunt potius, quam de necessitate [...]". 
Do tej kwestii ustosunkował się także Piotr Lombard w Rozdziale II Księgi IV „Liber sententiarum” stwierdzając: „W sprawowaniu [...] tego sakramentu, jak i w innych, coś należy do substancji małżeństwa, jak zgoda małżeńska, która sama wystarczy do zawarcia małżeństwa"34. Odnosząc się do waloru formalności prawnych w małżeństwach tajnych dodał on: „Bez nich więc nie jako prawowici małżonkowie, lecz jakby cudzołożni schodzą się, jak ci, którzy po kryjomu ślubują i zaiste byliby nierządni, gdyby nie wspierała ich wola, wyrażona na teraz, która czyni między nimi prawowite małżeństwo. Bo i ukryta zgoda na teraz, wyrażona słowami, czyni małżeństwo, chociaż nie ma tam uczciwej umowy"35.

W ówczesnej doktrynie utrzymywano, iż małżeństwa tajne były ważne w sferze wewnętrznej. Pojmowano je bowiem jako „res spirituales"36. Jak pisze Gaudemet, jedno z następstw takiego ujęcia wiązało się $\mathrm{m}$. in. $\mathrm{z}$ faktem, iż w tym wypadku nie można było wnieść skargi przeciwko władzy cieszącej się egzempcją ${ }^{37}$.

Oprócz tego, taki stan miał reperkusje praktyczne. Mianowicie ci, którzy zawarli takie małżeństwa, zawierając następnie związek publiczny popełniali grzech ciężki, żyjąc w permanentnym cudzołóstwie ${ }^{38}$. Nawiązując do tego wątku Freisen powołując się na Pseudoizydora wskazał, iż w średniowieczu obowiązywały takie zasady, iż tylko w małżeństwie kazirodczym strony powinny zostać rozdzielone, ponieważ tego typu związki były nielegalne; zasada ta natomiast nie dotyczyła związków zawieranych z pominięciem formalności prawnych ${ }^{39}$.

\footnotetext{
34 Zob. P. Lombard, Cztery Księgi Sentencji, t. 2, tłum. J. WojtKowski, Olsztyn 2015, s. 474.

35 TAMŻE.

36 Por. L. Nuzzo, Il matrimonio clandestino..., dz. cyt., s. 353 i s. 363: „Le unioni celebrate occultamente erano, di conseguenza, proibite e ritenuto pro infectis ma in ogni caso, in virtú del principio per cui le formalità non attenevano alla sostanza del sacramento del e che la loro osservanza era solo consigliata ma non imposta, una volta contratte, non era possibile scioglierle".

37 Por. J. Gaudemet, Il matrimonio..., dz. cyt., s.174.

38 Por. L. Nuzzo, Il matrimonio clandestino..., dz. cyt., s. 353.

39 Por. J. Freisen, Geschichte..., dz. cyt., s. 74: „Nur die incestuosen Ehen müssen nach Ps. Isidor getrennt werden, nich aber die ohne Formalitäten eingegangene Ehe”.
} 
Według Nuzzo, przyjęcie takiego rozwiązania systemowego wynikało $\mathrm{z}$ dwóch powodów: teologicznego i politycznego. Teologicznie, jeśli małżeństwo było instrumentem służącym do udzielenia człowiekowi łaski, to do jego ważności wystarczyło wyrażenie zgody małżeńskiej przez nupturientów ${ }^{40}$. $Z$ aspektu politycznego natomiast Kościół realizował pewien program wiążący się z pozbawieniem kompetencji władzy świeckiej względem małżeństwa ${ }^{41}$.

Wypełnienie formalności prawnych było istotne jedynie $\mathrm{z}$ aspektu dowodowego. Ich zawarcie dowodzono z oświadczeń stron oraz zeznań świadków. Prawnie natomiast zawieranie małżeństw tajnych było jedynie niegodziwe ${ }^{42}$. Zdaniem Freisena, za tezą, iż formalności nie miały istotnego znaczenia przy zawieraniu małżeństwa przemawia również inny fakt, mianowicie, za pominięcie „sollemnitates” nigdy nie przewidywano nałożenia $\operatorname{kar}^{43}$.

40 Por. L. Nuzzo, Il matrimonio clandestino..., dz. cyt., s. 352.

41 TAMŻE: „La natura sacramentale e consensualistica, riconosciuta dalla dottrina teologica e canonica all'unione tra un uomo e una donna, comportò necessariamente il principio dell'aformalità del matrimonio o meglio della non necessarietà nella materia matrimoniale di formalità ad substantiam. A favore di questa scelta militavano due diversi ordini di motivazioni, uno di carattere teologico, l'altro politico. Se infatti, il matrimonio era uno strumento che Christo aveva dato agli uomini per permettere loro di ottenere la grazia unificante e se per il suo perfezionamento era sufficiente il solo consenso dei nubenti liberamente manifestato, non appariva ammissibile subordinare la sua validità all'osservanza di prescrizioni vincolanti. D’altra parte non ritenere necessaria alcuna formalità nella celebrazione di un matrimonio compratava anche delle conseguanze di natura politica. Si può sostenere, infatti, che la spiritualizzazione del vincolo coniugale e il rifiuto di sollemnitas ad substantiam furono gli strumenti attraverso i quali la Chiesa persequi la realizazione di un programma, volto a sottrare alla legislazione civile la competenza in materia matrimoniale".

42 TAMŻE, s. 364.

43 Por. J. Freisen, Geschichte..., dz. cyt., s. 148: „Der beste Beweis dafür, da $\beta$ die Kirche niemals die Sollemnitäten deart betonte, da $\beta$ ihr Fehlen das Verhältnis zu einem außerehelichen machte, liegt in der Tatsache, da $\beta$ się fast nirgends Strafen für die Nichtbeachtung dieser Sollemnitäten finden". 


\section{Zakończenie}

Z przeprowadzonych analiz wynika, iż w średniowiecznej rzeczywistości zawarte małżeństwa tajne były ważne. Pominięcie bowiem formalności prawnych nie skutkowało nieważnością aktu prawnego podjętego przez nupturientów. „Sollemnitates” były w prawdzie komponentami wprowadzonymi do struktury prawnej małżeństwa, ale niewymaganymi do ważności aktu. Wypełnienie tego typu warunków było jedynie istotne dla celów dowodowych.

Niemniej jednak zawieranie tego typu związków w ówczesnej rzeczywistości stwarzało wiele problemów. $Z$ jednej bowiem strony $\mathrm{w}$ średniowieczu występowały liczne związki bigamiczne i poligamiczne $^{44}, \mathrm{z}$ drugiej zaś zawarcie małżeństw tajnych bardzo trudno było udowodnić na drodze procesowej ${ }^{45}$.

Dlatego też Kościół zaczął się sprzeciwiać zawieraniu tego typu związków. Wyrazem czego były postanowienia Soboru Laterańskiego IV (1215r.). W konstytucji bowiem 51, 2 stanowiono: „[...] zakazujemy całkowicie małżeństw potajemnych i zabraniamy, by jakikolwiek kapłan ośmieliłby się przy nich asystowac" ${ }^{46}$.

Kres zawieraniu tego typu związków położył Sobór Trydencki wprowadzając przepisy o formie kanonicznej ${ }^{47}$. Przy tym należy zauważyć, iż dyskusja nad tym problemem nie była łatwa. Reinhard Lettmann w swej monografii „Die Diskusion über die klandestinen Ehen und die Einführung einer zur Gültighkeit verpfilichtenden Eheschliessungsform auf dem Konzil von Trient" poświęconej dyskusji soborowej na ten temat wskazał, iż dla ojców soborowych poważny problem stanowiła kwestia czy Kościół może poprzez swą ingerencję

\footnotetext{
44 Por. L. Nuzzo, Il matrimonio clandestino..., dz. cyt., s. 353.

45 Por. R. Rasi, La conclusione..., dz. cyt., s. 159-160.

46 Por. Sobór Laterański IV-1215, Konstytucja 51,2, w: A. BAron, H. Pietras (red.), Dokumenty Soborów powszechnych, t. 2, Kraków 2003, s. 293; J. GAUDEMET, Il matrimonio..., dz. cyt., s. 174; J. UMı́́ski, Historia Kościoła, t. 1., Opole 1959, s. 399. 47 Por. Sobór Trydencki (1545-1563). Kanony o reformie małżeństwa, w: A. BARoN, H. Pietras (red.) Dokumenty Soborów powszechnych, t. 4, Kraków 2005, s. 723.
} 
w prawną strukturę małżeństwa przeszkodzić ważnemu małżeństwu sakramentalnemu ${ }^{48}$.

Kończąc te rozważania pragnę zwrócić uwagę, iż funkcjonowanie małżeństw tajnych w obowiązującej kodyfikacji (kan. 1130-1133 KPK) znacznie różni się od instytucji funkcjonującej w średniowieczu. Obecnie bowiem jej istota wiąże się zachowaniem tajemnicy w różnych fazach postępowania związanego z zawieraniem małżeństwa ${ }^{49}$; w epoce kanonistyki klasycznej natomiast szło o związki zawierane z pominięciem formalności prawnych.

\section{The Legal Value of Secret Marriages in the Times of Classical Canon Law}

\section{Summary}

By analysing source materials and present canonistic thought the author of the presented article proved that in medieval times secret marriages were legal. Disregarding legal formalities did not result in the invalidity of a legal act contracted by the nupturients. Although legal formalities were components introduced to the legal structure of marriage, they were not necessary in order for the marriage to be valid. Fulfilling the formal conditions was important only for evidential purposes.

Moreover, the author proved that secret marriages in current codification (Cann. 1130-1133 CIC) work significantly different from how they functioned in the Middle Ages. In present times, the essence of this institution entails keeping secret specific stages of contracting marriage; in the times of Classical Canon Law, on the other hand, the aim was to contract marriage without fulfilling legal formalities.

\footnotetext{
48 Por. R. Lettmann, Die Diskusion über die klandestinen Ehen und die Einführung einer zur Gültighkeit verpfilichtenden Eheschliessungsform auf dem Konzil von Trient, Münster 1966, s. 30-117.

49 Por. G. DzIERżon, Zawieranie małżéstw tajnych, Ius Matrimoniale 11 (2006) nr 17, s. 110.
} 